\title{
Changes in the quality characteristics of cricket (Gryllus bimaculatus) under various processing conditions
}

\author{
Eun-Mi Kim ${ }^{1}$, Jeong-Ho Lim ${ }^{1 *}$, Yoon-Je Chang ${ }^{1}$, Seong-Hwan An ${ }^{2}$, Mi-Young Ahn ${ }^{3}$ \\ ${ }^{1}$ Korea Food Research Institute, Seongnam 463-746, Korea \\ ${ }^{2}$ Naturals Co., Ltd., Gunpo 435-050, Korea \\ ${ }^{3}$ Department of Agricultural Biology, Nacdemy of Agricultural Science, RDA, Jeonju 560-500, Korea
}

\section{가공조건에 따른 귀뚜라미의 식품학적 품질 특성 변화}

\author{
김은미 ${ }^{1} \cdot$ 임정호 $^{1 *} \cdot$ 장윤제 ${ }^{1} \cdot$ 안성환 $^{2} \cdot$ 안미영 ${ }^{3}$ \\ 1한국식품연구원, ${ }^{2}$ 주)네 츄럴스, ${ }^{3}$ 농촌진흥청
}

\begin{abstract}
Crickets have been used as crude drug for treating fever and hypertension in East Asia. This study was carried out to investigate the quality characteristics such as the microbial and nutrient contents of crickets (Gryllus bimaculatus) prepared with various processing conditions for use as food. These conditions included the lyophilization process (LP), hot-air process $\left(\mathrm{HP}, 9^{\circ} \mathrm{C}\right.$ for $7 \mathrm{hr}$ ), roasting process $\left(\mathrm{RP}, 160^{\circ} \mathrm{C}\right.$ for $\left.40 \mathrm{~min}\right)$, and frying process $\left(\mathrm{FP}, 180^{\circ} \mathrm{C}\right.$ for $30 \mathrm{sec}$ ). The total bacterial population of the crickets was $5 \sim 7 \log \mathrm{CFU} / \mathrm{g}$, but Coliform and E. coli were not detected. The major fatty acids in all the samples were palmitic acid (C16:0), oleic acid (C18:1), and linoleic acid (C18:2). The level of polyunsaturated fatty acids was highest $(63.55 \mathrm{~g} / 100 \mathrm{~g})$ in the LP-processed crickets. As for the amino acid content, the glutamic acid level was highest in all the samples, and the RP and FP decreased by $12.01 \%$ and $53.88 \%$, respectively, compared to that of the LP. The mineral contents were highest in the LP-processed crickets. Hg was detected at about $1.0 \mathrm{ppb}$ in all the samples, but its level was lower than the residue tolerance level in the Korean Food Code. Such conditions should be considered to better understand the quality characteristics of crickets in food processing.
\end{abstract}

Key words : cricket, Gryllus bimaculatus, process, quality

\section{서 론}

2000년대 이후 곡물소비량의 증가와 지구온난화로 인한 곡물공급의 변동성이 높아지고 있는 가운데, $\mathrm{UN}$ 의 세계 인구 전망 보고서에서는 2050년도에는 전 세계 인구가 96 억 명으로 증가할 것으로 전망하여 식량 공급에 대한 중요 성이 부각되고 있다(1). 또한 FAO는 향후 2050년의 동물성 단백질의 수요는 2007 년의 육류소비의 2 배에 이를 것으로

*Corresponding author. E-mail : jhlim@kfri.re.kr

Phone : 82-31-780-9331, Fax : 82-31-780-9343

Received 16 March 2015; Revised 3 April 2015; Accepted 8 April 2015.

Copyright (c) The Korean Society of Food Preservation. All rights reserved.
전망하며, 축산물의 소비는 고가의 사치품이 될 것을 예측 하고 있다(2)

이에 대한 대안으로서 최근 식품 공급원으로서의 곤충에 대한 관심이 증가하고 있는 실정이다(3). 현재 아프리카, 아시아, 라틴아메리카에서는 전통적으로 수백 종의 곤충이 섭취되고 있다(4).

국내에서도 현행 '벼메뚜기(Oxya japonica japonica (Thunberg))'와 '식용누에번데기(silkworm pupa, Bombyx $M o r i \mathrm{~L}.)^{\prime}$ 에 대한 식품 사용에 대한 법적 근거는 식품공전에 마련되어 있으며, 다양한 종류의 곤충자원에 대한 식품기 반을 구축하기 위해 노력하고 있다(5).

귀뚜라미(귀뚜라밋과; Scapsipedus Aspersus)는 메뚜기 목 귀뚜라밋과의 곤충으로 한국을 비롯한 동남아시아에서 널리 분포한다(6). 몸길이가 약 $1.7 ~ 2.1 \mathrm{~cm}$ 이고 잡식성이며 
8 10월에 출현빈도가 높은 곤충으로 알려져 있다

귀뚜라미는 한의학에서 '실솔'이라고 하였으며, 최근에 는 알코올 분해 대사 촉진과 강장제로 효과가 있는 것으로 발표되었다(7). 현재에도 민간약재로도 사용되고 있으나, 식품공전에 등록되어 있지 않아 식품으로 제조 및 판매가 불가능하다.

귀뚜라미는 과수나 각종 묘목을 갉아먹는 곤충으로 민간 에서는 구워서 어린아이의 경기에 사용하거나, 해열제로 사용하기도 하였다. 또한, 일본에서는 설사, 이질 및 장티푸 스를 치료하는데 사용하였으며, 17 세기 유럽에서는 결석의 치료 및 이뇨제로 사용하기도 하였다(8). 또한, 귀뚜라미는 아시아, 페루, 콜롬비아, 태국 및 나이지리아에서 전통적으 로 식용 섭취된 곤충이었으며(3), 최근 미국과 영국에서도 식용곤충이 상품으로 출시되고 있는 실정이다.

최근 귀뚜라미에 대한 연구로는 $\mathrm{FAO}$ 를 중심으로 식용 귀뚜라미의 식품으로서의 안전성 증진 및 영양공급원의 고급화에 대한 연구 투자가 활발히 진행되고 있으며(9), 국내에서는 귀뚜라미 사료에 첨가 급여 시 계육에서 필수지 방산 및 다가불포화 지방산이 증가(10), 급성간염에 귀뚜라 미 추출물의 보호효과 등에 대한 연구가 있으나(11), 귀뚜라 미의 영양가나 가공 및 저장방법 등에 대한 연구는 미미한 실정이다.

귀뚜라미는 불포화지방산이 높으며, 고단백 식품으로서 의 가치가 인정되어지고 있어(12), 이들의 식품으로서의 활용도를 높이는 한 방법으로서 다양한 가공방법에 따른 성분들의 변화에 대한 연구가 미이용 자원의 식량자원으로 서의 이용에 크게 도움이 되리라 판단된다.

따라서 본 연구는 귀뚜라미의 가공 조건에 따른 식품학 적 품질특성 및 위생학적 품질 변화를 조사하고자 하였다.

\section{재료 및 방법}

실험재료

본 연구에 사용된 귀뚜라미는 2013년도에 정선의 사육 농장에서 채집하여 3 일간의 배변 기간을 거친 후 동결한 제품을 구입하여 사용하였다. 구입한 시료는 냉장고에서 24시간동안 해동시키고 3회의 수세척을 한 후 채반에 옮겨 $10^{\circ} \mathrm{C}$ 에서 2 시간 동안 자연 탈수를 실시하여 가공시료로 사용하였다.

\section{가공조건}

동결건조 : 시료를 $-70^{\circ} \mathrm{C}$ 에서 24 시간 동결한 후 동결건조 기(FD5508 Freeze dryer, Ilshin lab, Co., Ltd., Seoul, Korea) 를 이용하여 수분이 완전히 제거될 때까지 건조한 후 분쇄 기로 분쇄하여 $80 \mathrm{mesh}\left(\Phi 250 \mathrm{~mm}^{2}\right)$ 의 망을 통과한 것을 시료로 사용하였다.
열풍건조 : 시료를 $90^{\circ} \mathrm{C}$ 에서 7시간 열 풍건조기(OF-02, Jeio Tech, Daejeon, Korea)를 이용하여 건조한 시료를 분쇄 기로 분쇄하여 $80 \mathrm{mesh}\left(\Phi 250 \mathrm{~mm}^{2}\right)$ 의 망을 통과한 것을 시료로 사용하였다.

볶음건조 : 시료를 볶음기(CBR-101A, Gene Cafe, Ansan, Korea)를 이용하여 $160^{\circ} \mathrm{C}$ 에서 40 분간 볶은 후 시료를 분쇄 기로 분쇄하여 $80 \mathrm{mesh}\left(\Phi 250 \mathrm{~mm}^{2}\right)$ 의 망을 통과한 것을 시료로 사용하였다.

튀김건조 : 시료를 튀김기(FR402373, Tefal, Rumilly, HauteSavoie, France)에서 대두유(Soybean oil, CJ Cheiljedang, Seoul, Korea)를 이용하여 $180^{\circ} \mathrm{C}$ 에서 30 초간 튀긴 후 외부의 유지를 흡착포로 제거한 후 분쇄기를 이용하여 분쇄하여 $80 \mathrm{mesh}\left(\Phi 250 \mathrm{~mm}^{2}\right)$ 의 망을 통과한 것을 시료로 사용하였다.

\section{일반성분 분석}

귀뚜라미의 일반성분 분석은 $\mathrm{AOAC}$ 법(13)에 따라 수분 은 $105^{\circ} \mathrm{C}$ 상압가열건조법, 단백질은 Kjeltec system(kjeltec auto sampler system 8240 analyzer, Foss Tecator, Hilleroed, Denmark), 조지방은 diethyl ether에 의한 Soxhlet 추출법, 조회분은 $550{ }^{\circ} \mathrm{C}$ 회화법, 조섬유는 $1.25 \%$ 황산 분해법을 이용하여 측정하였다. 귀뚜라미의 일반성분을 $100 \%$ 로 하 고 이것에서 수분, 단백질, 지방, 회분 및 섬유의 함량을 뺀 나머지를 nitrogen free extract(NFE)라고 하여 탄수화물 함량을 나타내었다. 네 가지 건조 방법에 따른 귀뚜라미의 키틴 함량은 Hackman의 단리법을 응용하여 측정하였다 (14).

\section{구성아미노산}

아미노산 분석은 각 시료 약 $1.0 \mathrm{~g}$ 을 정확히 취하여 ample 에 넣고 $6 \mathrm{~N} \mathrm{HCl} 15 \mathrm{~mL}$ 를 가한 다음 $\mathrm{N}_{2}$ 로 치환하여 신속하 게 밀봉하였다. 이를 $105^{\circ} \mathrm{C}$ 오븐에서 24시간 가수분해 시킨 뒤 방냉하여 탈이온수로 $50 \mathrm{~mL}$ 정용플라스크에 정용 후, $0.2 \mu \mathrm{m}$ membrane 필터로 여과하였다. 여액 $2 \mathrm{~mL}$ 를 취해 $25 \mathrm{~mL}$ 정용한 후, 이를 AccQ-Tag 방법(15)으로 유도체화 (AccQ-Fluor Reagent Kit, Waters corporation, Milford, MA, USA) 시키고 아미노산 분석기(pump PU-980, detector FP-920, autosampler AS-950-10, Jasco, Easton, MD, USA)를 이용하여 아미노산을 분석하였다. 이때 구성아미노산 분석 조건은 칼럼은 Nova-Pak $\mathrm{C} 18(3.9 \times 150 \mathrm{~mm}$, Waters corporation, Milford, MA, USA), 주입 량은 $10 \mu \mathrm{L}$, 칼럼 온도 는 $30^{\circ} \mathrm{C}$, 검출기는 fluorescence(Ex. $250 \mathrm{~nm}, \mathrm{Em} .395 \mathrm{~nm}$ ), 이동상은 $0.14 \mathrm{M}$ sodium acetate(A), $60 \%$ acetonitrile(B)의 gradient법(15)으로 분석하였다. 이때 사용한 시약은 특급 및 HPLC용을 사용하였으며, 아미노산 표준물질은 amino acid standard(Sigma Chemical Co., St. Louis, MO, USA)를 사용하였다. 
지방산

네 가지 가공조건에 따른 귀뚜라미의 지방산 분석은 Folch 등(16)의 방법에 따라 $2: 1(\mathrm{v} / \mathrm{v})$ 로 chloroform과 methanol을 섞은 용액으로 추출하였고, 추출된 지질은 Morrison 등(17)의 방법에 준하여 전처리 후 gas chromatography 를 사용하여 분석하였다. Gas chromatography 조건은 capillary column(SP-2380, film thickness $0.25 \mu \mathrm{m}$, SUPELCO Inc, Bellefonte, PA, USA)을 이용하였고 injection 온도는 $250^{\circ} \mathrm{C}$ 이었으며 검출기 온도는 $260^{\circ} \mathrm{C}$ 로 유 지하였다.

\section{무기질 및 중금속 분석}

귀뚜라미 시료에 함유된 무기질 성분은 식품공전의 무기 질 성분 분석법과 $\mathrm{AOAC}$ 방법(13)에 따라 분석하였고, $\mathrm{Ca}$, $\mathrm{Mg}, \mathrm{Mn}, \mathrm{Fe}, \mathrm{Zn}, \mathrm{Cu}$ 등의 성분을 측정하였다. 무기질 성분의 분석은 유도결합플라즈마 원자방출분광기(ICP-AES Optima 4300DV, Perkin Elmer, Inc. Waltham, MA, USA)를 사용하 였으며, 음이온 성분인 $\mathrm{Cl}$-와 $\mathrm{SO}_{4}{ }^{2-}$ 의 정량에 이용한 이온크 로마토그래프(Ion Chromatograph, IC)는 Dionex사(DX120 , Dionex, Sunnyvale, CA, USA)의 것을 사용하였으며 분석조건은 eluent로 $\mathrm{Na}_{2} \mathrm{CO}_{3} / \mathrm{NaHCO}_{3}$ 를 $\mathrm{AS} 14$ Column과 $1.2 \mathrm{~mL} / \mathrm{min}$ 의 flow rate 그리고 conductivity detector를 사용 하였다. 각 무기질의 검출 파장은 $\mathrm{Ca}: 393.366, \mathrm{P}: 213.618$, $\mathrm{K}:$ 766.491, Mg: 279.553, Mn: 257.610, Fe: 238.204, Zn: 213.856 및 $\mathrm{Cu}: 324.754 \mathrm{~nm}$ 이었다.

중금속 분석은 ICP-OES(Spectro Arcos, Spectro Analytical Instruments $\mathrm{GmbH}$, Kleve, Germany)를 이용하여 식품공전 의 규정에 따라 분석하였다. 원소별 측정 파장은 $\mathrm{Pb}$ : 220.353, Cd: 228.802, As: 193.696 및 $\mathrm{Hg}: 194.227 \mathrm{~nm}$ 로 측정하였다.

\section{미생물 분석}

네 가지 가공방법의 귀뚜라미의 미생물적 안전성을 확보 하기 위하여 식품공전의 규정에 따라 식중독균의 존재유무 와 총균수 및 대장균군에 대한 분석을 실시하였다. 병원성 미생물인 대장균(Escherichia coli O157:H7) 및 Salmonella $s p p$.에 대하여 Yoo 등(18)의 방법을 이용하여 존재유무를 확인하였다. 대장균(E. coli O157:H7)의 검사를 위하여 시 료 $25 \mathrm{~g}$ 을 $\mathrm{mEC}$ 배지( $\mathrm{mEC}$ broth with Novobiocin, Sigma Chemical Co.) $225 \mathrm{~mL}$ 에 넣고 $37^{\circ} \mathrm{C}$ 에서 24시간 동안 배양하 고, 배양액을 MacConkey sorbitol 한천배지(Sorbitol MacConkey II Agar with Cefixime and Tellurite, Becton, Dickinson and Company, Franklin lakes, NJ, USA)에 접종하 였다. 무색으로 확인된 집락을 $\mathrm{EMB}$ 한천배지(EMB broth, Sigma Chemical Co.)에 접종하고 $37^{\circ} \mathrm{C}$ 에서 24 시간 동안 배양하였으며, 대장균으로 추정되는 보라색 집락을 보통한 천배지(Nutrient agar, Difco Laboratories, Detroit, MI, USA)
에 접종 및 배양하여 그람염색법과 $\mathrm{O} / \mathrm{H}$ 혈청형 시험법을 통하여 분석하였다. Salmonella spp.의 검사를 위하여 시료 $25 \mathrm{~g}$ 을 peptone water $225 \mathrm{~mL}$ 에 넣고 $37^{\circ} \mathrm{C}$ 에서 24 시간 동안 배양하고, 배양액 $0.1 \mathrm{~mL}$ 을 Rappaport-Vassiliadis 배지 (Rappaport-Vassiliadis R10 broth, Difco Laboratories, Detroit, MI, USA) $10 \mathrm{~mL}$ 에 접종하고 $42^{\circ} \mathrm{C}$ 에서 24 시간 동안 배양하였다. XLD 한천배지(BD Xylose-Lysine-Desoxycholate agar, Becton, Dickinson and Company, Franklin lakes, NJ, $\mathrm{USA}$ )에 접종 후, 집락의 중앙부분이 검거나 붉으면 보통한 천배지에 접종하여 $37^{\circ} \mathrm{C}$ 에서 24시간 동안 배양하고, TSI 한천배지(Triple Sugar Iron Agar, Sigma Chemical Co.)에 접종 후, 살모넬라로 의심되는 성상여부를 관찰하였다. 살모넬라로 의심될 경우, 그람염색법과 $\mathrm{O} / \mathrm{H}$ 혈청형 시험법 을 이용하여 분석하였다.

귀뚜라미 시료에 존재하는 일반세균 및 대장균군에 대한 분석 방법은 다음과 같다. 시료 약 $1 \mathrm{~g}$ 을 채취하여 $0.85 \%$ 멸균 식염수에 단계적으로 희석한 후, 총균수는 plate count agar(Difco Laboratories, Detroit, MI, USA) 배지에 접종하였 고, 대장균과 대장균군은 chromocult agar(MERCK, Darmstadt, Germany) 배지에 접종하였다. 총균은 $36^{\circ} \mathrm{C}$ 에서 48 시간 배 양하였으며, 대장균군과 대장균은 $37^{\circ} \mathrm{C}$ 에서 48 시간 배양한 후 colony수를 측정하였다.

\section{통계처리}

실험 결과는 Statistical Analysis System(8.01, SAS, Chicago, IL, USA)를 이용하여 3번 반복 처리하여 평균과 표준편차를 계산하였고, 가공방법에 따라 귀뚜라미 시료의 특성에 차이가 있는지를 분산분석(ANOVA)를 통해 알아 보았으며, 사후분석은 Duncan's multiple range test 방법을 사용하여 $0.001 \%$ 수준에서 유의성을 비교하였다.

\section{결과 및 고찰}

일반성분 및 키틴함량

가공조건에 따른 귀뚜라미의 일반성분을 분석한 결과는 Table 1에 나타내었다. 수분함량은 튀김건조 조건이 $14.28 \%$ 로 가장 높았으며, 동결건조 조건에서 $1.44 \%$ 로 가장 낮았다. 조단백과 조회분은 반대로 튀김건조 처리구가 각 각 $26.48 \%, 1.74 \%$ 로 가장 낮았고, 동결건조 조건에서는 각 각 $64.44 \%, 5.42 \%$ 로 가장 높게 측정되었다. 조지방은 튀김 건조 처리구가 $45.87 \%$ 로 다른 처리구에 비해 높게 측정되 었다. 조섬유는 각각의 처리구에서 유사하게 측정되었다. 건조조건에 따라 귀뚜라미는 26.48 66.44\%의 단백질 함량 을 나타내고 있는데, Chen 등(19)의 연구결과에서도 메뚜기 목 곤충의 성충의 단백질 함량은 약 23 65\%임을 확인하였 다. 이는 식품 중 육류 $15.2 \sim 34.7 \%$, 어류 10.4 47.7\%의 범위 
Table 1. General compositions and chitin contents of cricket powder with different processing conditions

\begin{tabular}{ccccccc}
\hline & & LP $^{1)}$ & Hot-air $^{2)}$ & Roasting $^{3)}$ & Frying $^{4)}$ & Mean \\
\hline & Moisture (\%) & $1.44 \pm 0.02^{\mathrm{a}}$ & $7.25 \pm 0.03^{\mathrm{b}}$ & $12.63 \pm 0.13^{\mathrm{c}}$ & $14.28 \pm 0.63^{\mathrm{d}}$ & $8.90 \pm 5.26$ \\
& Crude protein (\%) & $64.44 \pm 0.11^{\mathrm{d}}$ & $62.19 \pm 0.65^{\mathrm{c}}$ & $55.08 \pm 0.07^{\mathrm{b}}$ & $26.48 \pm 0.21^{\mathrm{a}}$ & $52.05 \pm 15.84$ \\
& Crude fat (\%) & $15.53 \pm 0.19^{\mathrm{a}}$ & $15.47 \pm 0.43^{\mathrm{a}}$ & $17.27 \pm 0.18^{\mathrm{b}}$ & $45.87 \pm 0.04^{\mathrm{c}}$ & $23.54 \pm 13.49$ \\
\multirow{3}{*}{ General components } & Crude ash (\%) & $5.42 \pm 0.22^{\mathrm{d}}$ & $4.37 \pm 0.05^{\mathrm{c}}$ & $3.86 \pm 0.03^{\mathrm{b}}$ & $1.74 \pm 0.01^{\mathrm{a}}$ & $3.85 \pm 1.41$ \\
& Crude fiber (\%) & $10.38 \pm 0.17^{\mathrm{c}}$ & $9.32 \pm 0.01^{\mathrm{a}}$ & $10.07 \pm 0.04^{\mathrm{b}}$ & $10.02 \pm 0.14^{\mathrm{b}}$ & $9.95 \pm 0.42$ \\
& $\mathrm{NFE}^{5)}(\%)$ & $2.79 \pm 0.30^{\mathrm{b}}$ & $1.40 \pm 0.24^{\mathrm{a}}$ & $1.19 \pm 0.18^{\mathrm{a}}$ & $1.61 \pm 0.24^{\mathrm{a}}$ & $1.72 \pm 0.70$ \\
\hline & & $9.77 \pm 0.06^{\mathrm{b}}$ & $12.25 \pm 0.05^{\mathrm{c}}$ & $11.27 \pm 0.05^{\mathrm{c}}$ & $6.36 \pm 0.33^{\mathrm{a}}$ & $9.91 \pm 2.39$ \\
\hline
\end{tabular}

${ }^{1)}$ Lyophilization process.

${ }^{2)}$ Hot-air process $\left(90^{\circ} \mathrm{C}\right.$ for $7 \mathrm{hr}$ ).

${ }^{3)}$ Roasting process $\left(160^{\circ} \mathrm{C}\right.$ for $\left.40 \mathrm{~min}\right)$.

${ }^{4)}$ Frying process $\left(180^{\circ} \mathrm{C}\right.$ for $\left.30 \mathrm{sec}\right)$.

${ }^{5)}$ Nitrogen free extract.

를 가지는 것과 비교하여 귀뚜라미가 높은 단백질함량을 가지는 것을 알 수 있었다(20). 따라서 귀뚜라미가 기존의 단백질 식이급원을 대체할 수 있는 식품소재로서의 이용 가능성이 높다고 할 수 있겠다. 튀김건조한 귀뚜라미의 지 방함량은 $45.87 \%$ 로 동결건조, 열풍건조 및 볶음건조한 귀 뚜라미의 지방함량인 $15.47 \sim 17.27 \%$ 보다 증가한 것을 확인 할 수 있었다. 이러한 결과는 $160 \sim 180^{\circ} \mathrm{C}$ 의 고온에서의 튀김 가공 중 시료 내의 수분은 급격히 증발하고 수분 대신 기름 이 흡수되어 지방함량이 증가한 것으로 판단된다(21).

가공조건에 따른 귀뚜라미의 키틴 함량은 Table 1 에 나타 내었다. 건조 공정에 따른 키틴 함량은 6.36 12.25\%로 측정 되었다. 열풍건조 처리구의 키틴 함량이 가장 높게 나타났 으며, 볶음건조, 동결건조 및 튀김건조 순으로 나타났다. 열풍건조에 의한 키틴함량은 약 $12 \%$ 로, 튀김건조 $6 \%$ 의 약 2 배 높은 함량이었다. 키틴은 불용성 탄수화물로, 귀뚜 라미와 같은 곤충들의 외피를 구성하는 주성분으로서 면역 력을 높이는 효과가 있어 건강기능식품으로 이용되고 있다 $(22,23)$. 따라서 현행 다양하게 진행되고 있는 식품에의 키 틴 유도체 관련 연구에서 귀뚜라미의 활용성이 높을 것으로 판단된다.

\section{아미노산함량}

가공조건에 따른 귀뚜라미의 구성아미노산 함량은 Table 2 에 나타내었다. 건조공정 중 열풍건조 처리구의 필수아미 노산 함량이 $38.81 \%$ 로 가장 높은 값을 나타내었으며, 볶음 건조, 튀김건조 및 동결건조 처리구 순으로 각각 $38.31 \%$, $37.89 \%$ 및 $37.74 \%$ 를 나타내었다. 아미노산은 일반적으로 필수아미노산과 비필수아미노산으로 구분될 수 있는데, 필 수아미노산은 인체에서 합성되지 않거나 충분하게 합성되 지 않기 때문에 음식을 통해 섭취해야 한다. 필수아미노산 중 valine과 leucine의 함량이 높게 나타났는데, leucine은 골격근에서 단백질 합성을 촉진시키는 것으로 알려져 있다 (24). 네 가지 가공방법의 귀뚜라미는 17 종의 아미노산을
Table 2. Amino acid contents of cricket powder with different processing conditions

\begin{tabular}{lcccc}
\hline \multirow{2}{*}{ Amino acid } & \multicolumn{4}{c}{ Processing (\%) } \\
\cline { 2 - 5 } & LP $^{1}$ & Hot-air $^{2)}$ & Roasting & Frying $^{4}$ \\
\hline Essential amino acid & & & & \\
Threonine & 4.39 & 4.34 & 4.21 & 4.31 \\
Valine & 7.45 & 7.45 & 8.16 & 6.49 \\
Isoleucine & 3.69 & 4.26 & 3.72 & 4.46 \\
Leucine & 7.64 & 8.11 & 7.63 & 8.07 \\
Phenylalanine & 4.01 & 3.95 & 3.95 & 3.88 \\
Lysine & 6.28 & 6.40 & 6.19 & 6.45 \\
Histidine & 2.56 & 2.62 & 2.56 & 2.56 \\
Methionine & 1.72 & 1.68 & 1.89 & 1.67 \\
\hline Total essential amino acids & 37.74 & 38.81 & 38.31 & 37.89 \\
\hline Non-essential amino acid & & & & \\
Aspartic acid & 9.77 & 9.85 & 9.81 & 8.51 \\
Serine & 6.03 & 5.79 & 6.18 & 4.66 \\
Glutamic acid & 12.14 & 12.34 & 12.04 & 12.15 \\
Glycine & 5.28 & 5.42 & 5.07 & 5.90 \\
Alanine & 9.01 & 9.07 & 9.09 & 11.14 \\
Tyrosine & 5.66 & 4.77 & 5.33 & 5.55 \\
Arginine & 6.98 & 7.06 & 6.82 & 6.79 \\
Cystine & 0.92 & 1.04 & 0.89 \\
Proline & 5.98 & 6.31 & 6.52 \\
\hline Non-essential amino acids & 62.26 & 61.19 & 61.69 & 62.11 \\
\hline \multicolumn{1}{c}{ Total amino acids } & 100.00 & 100.00 & 100.00 & 100.00 \\
\hline L & & & & \\
\hline
\end{tabular}

${ }^{1)}$ Lyophilization process.

${ }^{2)}$ Hot-air process $\left(90^{\circ} \mathrm{C}\right.$ for $\left.7 \mathrm{hr}\right)$.

${ }^{3)}$ Roasting process $\left(160^{\circ} \mathrm{C}\right.$ for $\left.40 \mathrm{~min}\right)$

${ }^{4}$ Frying process $\left(180^{\circ} \mathrm{C}\right.$ for $\left.30 \mathrm{sec}\right)$. 
골고루 함유하고 있어 영양학적인 측면에서도 우수한 식품 소재로 이용할 수 있을 것으로 판단된다.

\section{지방산 조성}

가공조건에 따른 귀뚜라미의 지방산 조성은 Table 3에 나타내었다. 지방산 함량은 귀뚜라미의 지방 $100 \mathrm{~g}$ 에 포함 된 지방산의 양으로 나타내었다. 동결건조 처리구의 불포 화지방산 함량은 $63.55 \mathrm{~g} / 100 \mathrm{~g}$ 으로 가장 높게 나타났으며, 포화지방산 함량은 $31.88 \mathrm{~g} / 100 \mathrm{~g}$ 으로 튀김건조한 귀뚜라미 가 가장 높은 것으로 측정되었다. 포화지방산 중에서는 palmitic acid의 함량이 가장 높았고, 불포화지방산의 경우 linoleic acid, oleic acid 순으로 높은 함량을 나타내었다. Linoleic acid의 함량은 가열 공정을 거치면서 감소하였고, 특히 튀김공정의 귀뚜라미는 $33.47 \%$ 의 가장 낮은 linoleic acid 함량을 보였다. 반면 palmitic acid는 가열공정을 거치 면서 함량이 증가하여 튀김공정의 귀뚜라미에서 $23.09 \%$ 의 가장 높은 함량을 보였다. 이는 Lim 등(25)과 Choe 등(26)의 연구에서 튀김 등 가열공정을 거치게 되면 불포화지방산은 감소하고, 포화지방산이 증가하게 된다는 결과와 유사함을 확인할 수 있었다.

Margaret 등(12)과 Kim 등(27)의 연구결과에서도 귀뚜라 미의 주요 포화지방산은 myristic acid, palmitic acid 및 stearic acid이고, 주요 불포화지방산은 oleic acid, linoleic acid 및 linolenic acid 임을 확인할 수 있었다. 귀뚜라미에는 체내에서 합성되지 않는 필수지방산인 linoleic acid와 linolenic acid를 포함한 다양한 불포화 지방산이 풍부하기 때문에, 귀뚜라미를 지방산 식이급원으로의 이용 가능성이 높다고 할 수 있겠다.

\section{무기질 및 중금속 조성}

가공조건에 따른 무기질 함량을 분석한 결과를 Table 4에 나타내었다. 동결건조 처리구의 무기질 함량이 가장 높게 나타났으며, 튀김건조 처리구에서 가장 낮은 무기질 함량을 보였다. 특히 튀김건조에 의하여 전반적인 무기질 함량이 감소하여 동결건조 처리구에 비하여 약 $20 \%$ 수준으 로 감소하였다.

귀뚜라미를 식품소재로 이용하기 위하여 유해물질에 대 해 분석한 결과는 Table 5 에 나타내었다. 귀뚜라미 소재의 안전성 확보를 위하여 납, 카드뮴, 비소 및 수은에 대하여 중금속 분석을 실시하였다. 동결건조와 열풍건조 처리구에 서 카드뮴이 $0.03 \mathrm{ppm}$ 수준으로 검출되었지만 이는 식약처

Table 4. Mineral contents of cricket powder with different processing conditions

\begin{tabular}{cccccc}
\hline Component & Unit & LP $^{1)}$ & Hot-air $^{2}$ & Roasting $^{3)}$ & Frying $^{4}$ \\
\hline $\mathrm{Ca}$ & & 0.25 & 0.23 & 0.20 & 0.05 \\
$\mathrm{P}$ & & 0.85 & 0.79 & 0.77 & 0.17 \\
$\mathrm{~K}$ & $\mathrm{mg} / 100 \mathrm{mg}$ & 0.98 & 0.95 & 0.90 & 0.18 \\
$\mathrm{Mg}$ & & 0.11 & 0.10 & 0.09 & 0.02 \\
\hline $\mathrm{Mn}$ & & 68 & 61 & 51 & 9 \\
$\mathrm{Fe}$ & \multirow{2}{*}{$\mathrm{ppm}$} & 76 & 60 & 45 & 16 \\
$\mathrm{Zn}$ & & 283 & 268 & 174 & 48 \\
$\mathrm{Cu}$ & & 12 & 12 & 14 & 4 \\
\hline
\end{tabular}

${ }^{1)}$ Lyophilization process.

${ }^{2}$ Hot-air process $\left(90^{\circ} \mathrm{C}\right.$ for $\left.7 \mathrm{hr}\right)$

${ }^{3}$ Roasting process $\left(160^{\circ} \mathrm{C}\right.$ for $\left.40 \mathrm{~min}\right)$

${ }^{4}$ Frying process $\left(180^{\circ} \mathrm{C}\right.$ for $\left.30 \mathrm{sec}\right)$.

Table 3. Comparison of fatty acid profiles of cricket powder with different processing conditions

\begin{tabular}{|c|c|c|c|c|c|}
\hline & \multirow{2}{*}{ Fatty acid } & \multicolumn{4}{|c|}{ Processing $(\mathrm{g} / 100 \mathrm{~g})$} \\
\hline & & $L P^{1)}$ & Hot-air' $\left.{ }^{2}\right)$ & Roasting ${ }^{3)}$ & Frying ${ }^{4)}$ \\
\hline \multirow{3}{*}{$\begin{array}{l}\text { Saturated fatty acid } \\
\text { (SFA) }\end{array}$} & Myristic acid (C14:0) & $\mathrm{ND}^{5)}$ & $0.48 \pm 0.42$ & $0.40 \pm 0.35$ & $0.46 \pm 0.40$ \\
\hline & Palmitic acid (C16:0) & $21.00 \pm 1.13$ & $21.66 \pm 1.31$ & $21.24 \pm 0.12$ & $23.09 \pm 0.08$ \\
\hline & Stearic acid (C18:0) & $9.07 \pm 1.74$ & $7.05 \pm 0.65$ & $7.86 \pm 0.92$ & $8.33 \pm 1.19$ \\
\hline \multirow{8}{*}{$\begin{array}{l}\text { Unsaturated fatty acid } \\
\text { (USFA) }\end{array}$} & Total saturated fatty acids & $30.07 \pm 0.96$ & $29.19 \pm 0.79$ & $29.51 \pm 0.46$ & $31.88 \pm 0.56$ \\
\hline & Palmitoleic acid (C16:1) & $\mathrm{ND}$ & $2.32 \pm 0.08$ & $2.08 \pm 0.27$ & $2.20 \pm 0.02$ \\
\hline & Oleic acid $(\mathrm{C} 18: \ln 9 \mathrm{c})$ & $20.40 \pm 1.18$ & $23.14 \pm 0.81$ & $23.63 \pm 0.39$ & $23.19 \pm 1.07$ \\
\hline & Linoleic acid (C18:2n6c) & $40.70 \pm 1.94$ & $34.29 \pm 1.24$ & $35.11 \pm 0.96$ & $33.47 \pm 0.25$ \\
\hline & Linolenic acid (C18:3n3) & $2.45 \pm 0.25$ & $1.49 \pm 0.09$ & $0.55 \pm 0.39$ & $1.35 \pm 0.15$ \\
\hline & Cis-11,14-Eicosadienic acid (C20:2) & $\mathrm{ND}$ & $0.42 \pm 0.73$ & $0.93 \pm 0.41$ & $0.53 \pm 0.46$ \\
\hline & Total unsaturated fatty acids & $63.55 \pm 0.56$ & $61.66 \pm 0.52$ & $62.30 \pm 0.42$ & $60.74 \pm 0.41$ \\
\hline & USFA/SFA & 2.11 & 2.11 & 2.11 & 1.91 \\
\hline
\end{tabular}

\footnotetext{
${ }^{1)}$ Lyophilization process.

${ }^{2}$ Hot-air process $\left(90^{\circ} \mathrm{C}\right.$ for $\left.7 \mathrm{hr}\right)$.

${ }^{3)}$ Roasting process $\left(160^{\circ} \mathrm{C}\right.$ for $\left.40 \mathrm{~min}\right)$.

${ }^{4)}$ Frying process $\left(180^{\circ} \mathrm{C}\right.$ for $\left.30 \mathrm{sec}\right)$.

${ }^{5}$ Not detected.
} 
고시(28)의 기준인 $0.2 \mathrm{ppm}$ 보다 낮은 것으로 확인하였다. 또한 수은은 모든 처리구에서 $0.3 ~ 1.2 \mathrm{ppb}$ 수준으로 검출되 었으나, 이 또한 식품허용기준인 $0.5 \mathrm{ppm}$ 과 비교할 때 $1 / 100$ 수준 이하인 것으로 나타났다. 반면 납과 비소는 모든 가공 방법에 따른 귀뚜라미에서 검출되지 않았다. 튀김건조 귀 뚜라미의 무기질 함량이 감소하는 것으로 나타난 것은 고온 의 튀김공정 중 수분과 기름의 치환 과정에서 지방용해도가 높은 무기물질 및 중금속의 손실이 발생되는 것으로 판단되 었다(21,29).

Table 5. Heavy metals contents of cricket powder with different processing conditions

\begin{tabular}{ccccc}
\hline Component & LP $^{1)}$ & Hot-air $^{2}$ & Roasting $^{3)}$ & Frying \\
\hline $\mathrm{Pb}(\mathrm{ppm})$ & $\mathrm{ND}^{5)}$ & $\mathrm{ND}$ & $\mathrm{ND}$ & $\mathrm{ND}$ \\
$\mathrm{Cd}(\mathrm{ppm})$ & 0.03 & 0.03 & $\mathrm{ND}$ & $\mathrm{ND}$ \\
$\mathrm{As}(\mathrm{ppm})$ & $\mathrm{ND}$ & $\mathrm{ND}$ & $\mathrm{ND}$ & $\mathrm{ND}$ \\
$\mathrm{Hg}(\mathrm{ppb})$ & 1.1 & 1.2 & 0.9 & 0.3 \\
\hline
\end{tabular}

${ }^{1)}$ Lyophilization process.

${ }^{2)}$ Hot-air process $\left(90^{\circ} \mathrm{C}\right.$ for $\left.7 \mathrm{hr}\right)$.

${ }^{33}$ Roasting process $\left(160^{\circ} \mathrm{C}\right.$ for $\left.40 \mathrm{~min}\right)$

${ }^{4)}$ Frying process $\left(180^{\circ} \mathrm{C}\right.$ for $\left.30 \mathrm{sec}\right)$.

${ }^{5}$ Not detected.

\section{유해미생물 분석}

가공조건에 따른 귀뚜라미의 미생물의 변화는 Table 6에 나타내었다. 일반미생물은 건조 전 귀뚜라미에서 $7 \log$ 수 준을 나타내었으며, 건조공정 중에서는 동결건조 공정이 가장 높은 $7 \log$ 수준이었고 볶음건조와 튀김건조 공정에 의해 약 $2 \log$ cycle이 감소한 $5 \log$ 수준으로 나타내었다. 전반적으로 일반세균은 검출되었으나, 대장균군은 검출되 지 않았다. 또한 병원성 미생물인 대장균(E. coli $\mathrm{O} 157: \mathrm{H7})$, Salmonella spp. 및 Staphylococcus spp.에 대한 정성분석 결과, 병원성 미생물은 검출되지 않았다.

Table 6. Changes in microorganisms of cricket powder with different processing conditions

\begin{tabular}{lccccc}
\hline \multirow{2}{*}{ Microorganism } & \multicolumn{5}{c}{ Processing (log CFU/g) } \\
\cline { 2 - 6 } & Control & LP $^{1)}$ & Hot-air $^{2)}$ & Roasting & Frying \\
\hline Total aerobic count & $7.64 \pm 0.01$ & $7.32 \pm 0.02$ & $6.92 \pm 0.04$ & $5.41 \pm 0.00$ & $5.23 \pm 0.32$ \\
Coliform count & $\mathrm{ND}^{5)}$ & $\mathrm{ND}$ & $\mathrm{ND}$ & $\mathrm{ND}$ & $\mathrm{ND}$ \\
Escherichia coli count & $\mathrm{ND}$ & $\mathrm{ND}$ & $\mathrm{ND}$ & $\mathrm{ND}$ & $\mathrm{ND}$ \\
Salmonella spp. count & $\mathrm{ND}$ & $\mathrm{ND}$ & $\mathrm{ND}$ & $\mathrm{ND}$ & $\mathrm{ND}$ \\
\hline${ }^{1)}$ Lyophilization process. \\
${ }^{2)}$ Hot-air process $\left(90^{\circ} \mathrm{C}\right.$ for $\left.7 \mathrm{hr}\right)$. \\
${ }^{3}$ Roasting process $\left(160^{\circ} \mathrm{C}\right.$ for $\left.40 \mathrm{~min}\right)$. \\
${ }^{4)}$ Frying process $\left(180^{\circ} \mathrm{C}\right.$ for $\left.30 \mathrm{sec}\right)$. \\
${ }^{5}$ Not detected.
\end{tabular}

\section{요 약}

본 연구는 귀뚜라미 소재를 식품으로서의 활용도를 높이 기 위하여 다양한 가공방법에 따른 품질 변화를 조사하였 다. 일반성분 중 조단백과 조회분 함량은 동결건조 처리구 에서 가장 높게 나타났고, 수분함량과 조지방은 튀김건조 처리구에서 가장 높게 나타났으며, 조섬유는 각각의 처리 구에서 유사하게 나타났다. 열풍건조 처리구의 키틴함량은 약 $12 \%$ 로 튀김건조 처리구의 $6 \%$ 의 약 2 배 높은 함량을 나타내었다. 동결건조 귀뚜라미 시료의 지방 $100 \mathrm{~g}$ 중에서 불포화지방산이 $63.55 \mathrm{~g}$ 으로 가장 높게 측정되었고, 포화지 방산은 튀김건조 처리구가 지방 $100 \mathrm{~g}$ 중에서 $31.88 \mathrm{~g}$ 으로 가장 높은 함랑을 나타내었다. 무기질 함량은 동결건조 처 리구에서 가장 높게 나타났으며, 열풍건조, 볶음건조 및 튀김건조 순으로 나타났다. 건조조건에 따른 귀뚜라미의 안전성을 알아보기 위하여 중금속과 미생물 분석을 한 결 과, 카드뮴과 수은이 검출되었으나 이는 각각 중금속의 식 약처 고시 기준인 $0.2 \mathrm{ppm}, 0.5 \mathrm{ppm}$ 보다 낮은 수준으로 나타났으며, 납과 비소는 모든 처리구에서 검출되지 않았 다. 또한 병원성 미생물도 모든 처리구에서 검출되지 않았다.

\section{References}

1. UN (2013) World population prospects : The 2012 Revision. UN, New York, NY, USA

2. Kwon DH (2012) 2050 World food demand prospects. World Agriculture, 139, p 41-54

3. Huis AV, Itterbeeck JV, Klunder H, Mertens E, Halloran A, Muir G, Vantomme P (2013) Edible insects : future prospects for food and feed security. FAO Forestry paper, 171, p 1-185

4. Srivastava SK, Badu N, Pandey H (2009) Traditional insect bioprospecting-As human food and medicine. Indian J Traditional Knowledge, 8, 485-494

5. Ministry of Agriculture, Food and Rural Affairs (2011) Act on fosterage and support of the insect industry. Act No. 10931. MAFRA, Korea.

6. Lee EA, Kwon OS (2013) The effect of invasive cricket species, Gryllus bimaculatus on the survival of Korean cricket species, Teleogryllus emma. Korean J Ecol Environ, 46, 67-74

7. Kim MA, Hwang JS, Yun EY, Kang PD (2014) Edible \& medicinal insects. RDA interrobang, Rural Development Administration, Korea, 119, p 1-20

8. Park KT (2001) Insect resources. World science publishing company, Seoul, Korea, p 202 
9. FAO (2011) Codex alimentarius commison E. development of regional standard for edible crickets and their products. FAO, Rome, Italy

10. Ahn MY, Ryu KS, Park BY, Kim DW, Kim, IS, Kim SH (2000) Effects of cricket supplements on the chicken meats and its eggs. Korean J Poult Sci, 27, 197-202

11. Ahn MY, Lee YW, Ryu KS, Lee HS, Kim IS, Kim JW, Lee YK, Kim ES, Kim YS (2002) Protective effects of water/methanol extracts of cricket on the acute hepatic damages in the ICR-mice induced by administration of CCl4. Korean J Food Sci Technol, 34, 684-687

12. Margaret G, Pensri W, Laurence D (1989) Fatty acid and lipid analysis of the house cricket, Acheta Domesticus. Insect Biochem, 19, 767-774

13. AOAC (1990) Official Methods of Analysis. Association of official analytical chemists, Washington DC, p 17, 37, 440

14. Hackman RH (1954) Studies on Chitin. I. Enzymatic degradation of chitin and chitin esters. Aust J Biol Sci, 7, 168-178

15. Waters Corporation (1993) Waters AccQ-Tag amino acid analysis system operator's manual number 154-02TP. Milford, MA, USA

16. Folch J, Lees M, Stanley GHS (1957) A simple method for the isolaton and purification of total lipides from animal tissues. J Biol Chem, 226, 497-509

17. Morrison WR, Smith LM (1964) Preparation of fatty acid methyl esters and dimethylacetals from lipids with boron fluoride-methanol. J Lipid Res, 5, 600-608

18. Yoo JM, Hwang JS, Goo TW, Yun EY (2013) Comparative analysis of nutritional and harmful components in Korean and Chinese mealworms (Tenebriomolitor). J Korean Soc Food Sci Nutr, 42, 249-254

19. Chen XM, Feng Y, Zhang H, Chen ZY (2010) Review of the nutritive value of edible insects. FAO, p 85-92

20. Korea Food and Drug Administration (2011) Food composition table. 8th ed, KFDA, Osong, Korea, p 3-116

21. Mo SM, Lee HS, Hyun KS, Hong SA (2000) Culinary arts. Kyomunsa, Seoul, Korea, p 192

22. Gullan PJ, Cranston PS (2000) The insects. An Outline of Entomology. 2nd Ed, Blackwell Publishing, Oxford, United Kingdom, p 1-470

23. Hong DS, Choi YJ, Jang JM, Lee JW (2011) The market trend analysis of chitin derivatives. J Chitin Chitosan, $16,65-71$

24. Garlick PJ (2005) The Role of Leucine in the Regulation of Protein Metabolism. J Nutr, 135, 1553-1556

25. Lim YH, Lee HY, Jang MS (1993) Quality properties of yu-kwa by the frying time of soybean oil. J Korean Soc Food Nutr, 22, 186-189

26. Choe EO, Lee JY (1998) Thermooxidative stability of soybean oil, beef tallow and palm oil during frying of steamed noodles. Korean J Food Sci Technol, 30, 288-292

27. Kim HS, Jung CE (2013) Nutritional characteristics of edible insects as potential food materials. Korean $\mathbf{J}$ Apiculture, 28, 1-8

28. Korea Food and Drug Administration (2006) KFDA Notification No. 2006-55, KFDA, Osong, Korea, p 1-56

29. Korea Food and Drug Administration (2007) What is methylmercury in food? KFDA, Osong, Korea, p 4 